\title{
RECENT BOOKS IN
}

\section{International}

\section{Relations}

\section{PROBLEMS OF STABILITY AND PROGRESS IN INTERNATIONAL RELATIONS}

\section{by Quincy Wright}

A series of essays on the central problems in international relations today which includes a discussion of the influence of politics, law, science, technology, psychology, education, and organization on the future of international institutions. 392 pages. $\$ 5.00$

\section{WORLD TRADE POLICIES \\ by Henry Chalmers}

The changing panorama from $1920-1953$ is surveyed in periodic accounts of the trade policies and measures of the principal nations against the political and economic background of the period. 584 pages. $\$ 7.50$

\section{LAW AND POLITICS IN THE WORLD COMMUNITY:}

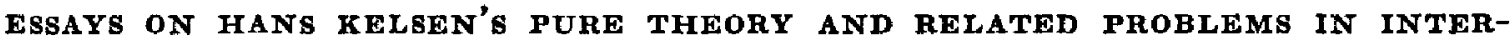
NATIONAL LAW

Compiled and edited by George A. Lipsky

Seventeen teachers and writers from around the world contribute to this symposium on the central features of Kelsen's teachings in international law, public law, and legal philosophy. 394 pages. $\$ 6.00$

\section{ZAIBATSU DISSOLUTION IN JAPAN}

\section{by T. A. Bisson}

This book explores the background of the Zaibatsu family combines and the Occupation's policy toward them in the light of the importance of this problem for U.S. policy in Asia. 326 pages. $\$ 5.00$

\section{THE ANGLO-IRANIAN OIL DISPUTE OF 1951-1952:}

A STUDY OF THE ROLE OF LAW IN THE RELATIONS OF STATES

by Alan W. Ford

An analysis of the unfolding of the dispute between Britain and Iran over nationalization of Iran's oil industry, and of the failure of the appropriate international institutions to deal with the dispute. 384 pages. $\$ 4.00$ 


\section{Complete Proceedings, 28th Institute Norman Wait Harris Memorial Foundation}

\section{THE WORLD INFLUENCE OF COMMUNISM}

Benjamin Schwartz, Nathon Leites, Samuel L. Sharp, Val Lorwin, Julian Towster, Alex Inkeles, Charles B. Marshall, and others discuss Communism in Europe, Asia, and Africa, organization and methods of Communist propaganda, and the counterattack of Americo and the West. 289 pp. $\$ 2.00$ postage prepaid.

Address orders to Norman Wait Harris Memorial Foundation, University of Chicogo, Chicogo 37, Illinois.

\section{PAST AND FUTURE by William $\mathrm{H}$. McNeill}

Mr. MCNeill, a brilliant young historian, presents an unusual interpretation of the past as the basis for an astute, speculative forecast of the future. $236 \mathrm{pp}$. $\$ 3.75$.

\section{FOUNDATIONS OF THE WORLD REPUBLIC by G. A. Borgese}

Here is a proposed world federation, not as a hopeless vision nor even as a cure for all the world's ills. In brilliant prose Mr. Borgese offers the blueprint of the first federal state of the world, a document whose objectives are peace and justice, not tyranny and farce. $336^{\prime} \mathrm{pp}$. $\$ 6.50$.

Send your orders for these two books to the

\section{UNIVERSITY OF CHICAGO PRESS 5750 Ellis Avenue, Chicago 37, Illinois}

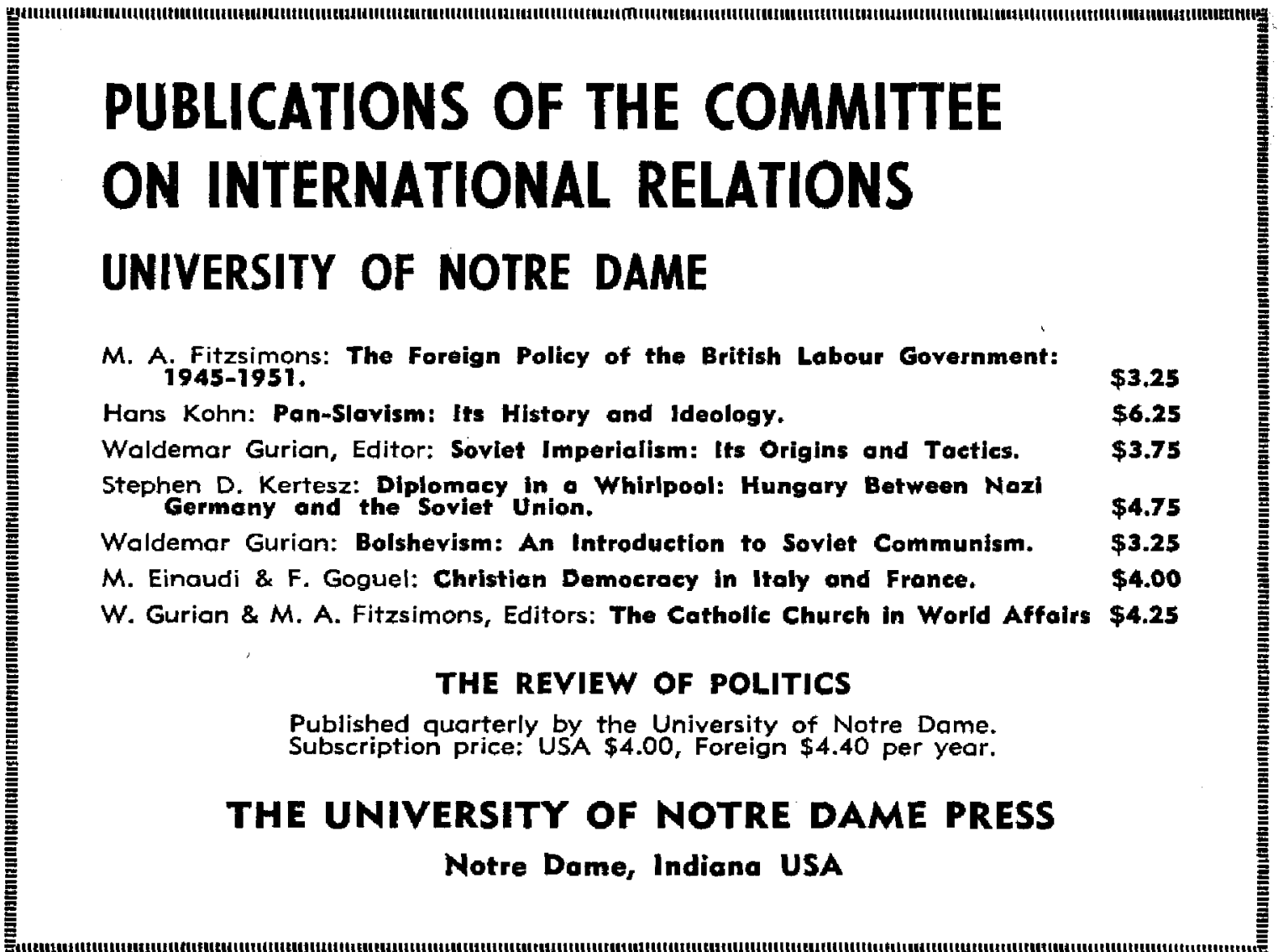




\section{The Frontiers of Economic Knowledge}

\section{Essays by Arthur F. Burns}

The views of Arthur F. Burns, chairman of President Eisenhower's Council of Economic Advisers, have taken on unusual importance in an economics-conscious America today. Here is the first rounded picture of his opinions on the timely, yet fundamental, questions of our nation's economy-inclading the dependability of economic forecasting, America's productive capacity, business cycle research, Keynesian thought, changes in income distribution, and trends of production. Published for the National Bureau of Economic Research.

376 pages. Charts.

$\$ 5.00$

\section{The China Tangle}

\section{By Herbert Feis}

"A calm and careful history of the American effort and policy in China has been greatly needed. Most fortunately, such a chronicle is now offered by Herbert Feis, a meticulous scholar, experienced in action, with a gift of disinterested, impersonal statement."-N.Y. Times Book Reviero.

"Dr. Feis's book surpasses the so-called 'White Paper on China' issued by the State Department and the official Army histories; in so doing the book comprises a splendid vindication of private scholarship in the field of government affairs." - Virginia Quarterly Review.

456 pages. Maps.

\section{The Origins of Soviet-American Diplomacy}

\section{By Robert Paul Browder}

"Scholarly, well-documented, and well-written . . . a dispassionate account of the motives leading to recognition of Rnssia in 1933, the high hopes entertained in Washington and Moscow as to its profitable consequences, and the swift disillnsionment which followed."-N.Y. Times Book Review.

268 pages.

$\$ 5.00$

Order through your bookstore, or from

PRINCETON UNIVERSITY PRESS PRINCETON, NEW JERSEY 